\title{
Radio frequency identification (RFID) technology as a strategic tool towards higher performance of supply chain operations in textile and apparel industry of Malaysia
}

\author{
Azlan Ali ${ }^{\mathrm{a}^{*}}$ and Muhammad Haseeb ${ }^{\mathrm{b}}$
}

${ }^{a}$ University College of Technology Sarawak, Malaysia

${ }^{b}$ Taylors Business School (TBS), Taylors University Lakeside Campus, 1 Jalan Taylors Subang Jaya Selangor Malaysia, Malaysia

C H R O N I C L E

Article history:

Received June 29, 2018

Accepted October 102018

Available online

October 102018

Keywords:

Supply Chain

Textile and Apparel $(T \& A)$

Radio Frequency Identification

(RFID)

Service Quality

ICT

Delivery Time

\section{A B S T R A C T}

\begin{abstract}
The Textile and Apparel industry of Malaysia used to contribute about $1.2 \%$ of gross domestic product (GDP) in the past. However, this position has followed a reverse trend in recent years. The imports were increased as compared to the exports which decreased the overall contribution of Textile and Apparel industry between 2015 and 2016. To address this issue, this study examined the effective supply chain activities through radio frequency identification (RFID) using survey method to collect the necessary data. Questionnaires were distributed among the employees of Textile and Apparel companies. While analyzing the data by using PLS-SEM, it was found that RFID was contributing majorly in supply chain operations and maintained significant and positive effect on the performance of supply chain. Moreover, staff services quality had moderating role between RFID and the operations of Textile and Apparel industry. The study is one of the first attempts to examine the effect of RFID on supply chain operations of Textile and Apparel companies. Thus, the current study is helpful for practitioners to resolve the issues of concerned industry.
\end{abstract}

(C) 2019 by the authors; licensee Growing Science, Canada

\section{Introduction}

Textile industry is one of the fastest growing industries which has meaningful contribution to the nation's economic growth in Malaysia (Pang \& Abdullah, 2013). From other manufacturing sectors, this sector contributes significantly in economic growth (Douglas, 1989). In Malaysia, this industry is the $3^{\text {rd }}$ major foreign exchange contributor after the electronic as well as palm oil industries (Lim et al., 2010; Azmi et al., 2018). Therefore, Malaysian Textiles and Apparels industry is the backbone of Malaysian economy.

Based on the past few year data, the Textile and Apparel (T\&A) industry of Malaysia has been contributing about $1.2 \%$ of gross domestic product (GDP) (Newspaper, 2017). The performance of industry up to 2014 was sufficient to contribute in economy. However, export data before 2014 demonstrated to be very positive and predicted bright future for this industry. Following by the previous years, in 2014, the imports were RM9.1 billion and exports were RM11.03 billion. Exports were excess

* Corresponding author

E-mail address: muhammad.haseeb@taylors.edu.my (M. Haseeb)

(C) 2019 by the authors; licensee Growing Science, Canada

doi: $10.5267 /$ j.uscm.2018.10.004 
than imports. However, now the situation is not in the favor of industry. Malaysian Textiles and Apparels sector declining in the export performance as compared to the imports which has negative influence on GDP.

During the year of 2008, Malaysian Textile and Apparel (T\&A) industry shows higher exports as compared to the imports. In this year, exports were RM5.10 billion higher than the imports. Between 2006 and 2007, this industry also showed high exports as compared to the imports. Exports were RM4.9 and RM4.7 billion in 2006 and 2007, respectively, which were higher than imports. This had significant impact on GDP as compared to the other industries. This industry was leading with important contribution in the economy.

However, this position became reversed in immediate few years. As it is shown in the Table 1, in 2015 and 2016, the imports were increased as compared to the exports. In 2015, imports were RM14.93 billion and exports were RM11.90 billion. In cases of 2016, imports were RM16.04 billion and exports were RM12.06 billion. In these two years, total balance was not in the favor of industry. In 2015 and 2016, imports were RM3.03 and RM4.34 billion higher than exports, respectively.

Table 1

Malaysian Textiles and Apparels Trading (2006-2016)

\begin{tabular}{cccc}
\hline Year & Import & Export & Balance \\
\hline 2006 & 6 & 10.9 & 4.9 \\
2007 & 5.6 & 10.3 & 5.7 \\
2008 & 5.4 & 10.5 & 5.1 \\
2009 & 4.4 & 8.93 & 3.53 \\
2010 & 5.65 & 9.33 & 2.64 \\
2011 & 8.17 & 10.81 & 0.55 \\
2012 & 8.91 & 9.46 & 1.47 \\
2013 & 8.78 & 10.25 & 1.92 \\
2014 & 9.1 & 11.03 & -3.03 \\
2015 & 14.93 & 11.9 & -4.34 \\
\hline 216 & 16.4 & 12.06 & 2 \\
\hline
\end{tabular}

Source: Developed by the current study

Malaysian Textiles and Apparels Industry needs to explore the reasons of low performance and needs to find remedies. In the context of current study, in Textiles and Apparels Industry, supply chain is one of the important sectors, which has important contribution. As the supply chain activities have major role in Textiles and Apparels Industry of every country (Keung Kwok \& Wu, 2009). Low performance of supply chain practices in this industry has significant negative influence on overall performance. As it is one of the most important elements of the textile industry (Keung Kwok \& Wu, 2009).

The industries shall emphasis on contemporary as well as modernization of management, technology advancement on automation to enhance the performance through supply chain. Therefore, to address the above issues in Malaysian Textiles and Apparels, the current study comes up with supply chain strategies to determine the possible issues. This study is one of the attempts to boost this industry performance through effective supply chain activities by using radio frequency identification (RFID). Hence, the primary objective of the current study is to investigate effective supply chain activities through RFID to enhance Malaysian Textiles and Apparels Trading volume. However, the subobjectives are as follows;

1. To investigate the role of effective delivery system and information communication technology (ICT).

2. To investigate the moderating role of staff services quality.

This study has major contribution in literature. As this study is one of the first study which creates a link between the implementation of supply chain practices and improvement of Malaysian Textiles and Apparels sector. In rare cases any study formally documented the issue of low trading performance of 
this sector through better supply chain management practices. This study reveals that staff services quality has significant contribution towards higher performance among textile firms. Effective delivery system, better use of information communication technology and good services can fix the issue in this industry. Thus, the study has multiple contribution in literature.

Practically, this study is important for Malaysian Textiles and Apparels firms to apply the current study to boost their supply chain operations. The current study is also helpful for practitioners to resolve the issue of this industry. Therefore, the current study contributed theoretically as well as practically.

\section{Literature Review}

Radio frequency identification (RFID) technology is based on information communication technology (ICT) and it has recently been used for developing technology in Hong Kong. It encourages the accomplices to gather constant information at each point-of-sale (POS), which is powerful in imagining real offers of advertise patterns. The technology is additionally gainful for clients making choices in the best way to match different garments inside a couple of minutes which increases the quality of the services and decreases the issue in delivery time. In some retail shops, RFID labels are connected to fashionable garments, and afterward used to catch client inclinations and screen stock at every progressively. Notwithstanding, this technology is being connected to traceability of the orders in a store network (Kelepouris et al., 2007), which is helpful to change on productivity of item (Zare Mehrjerdi, 2008).

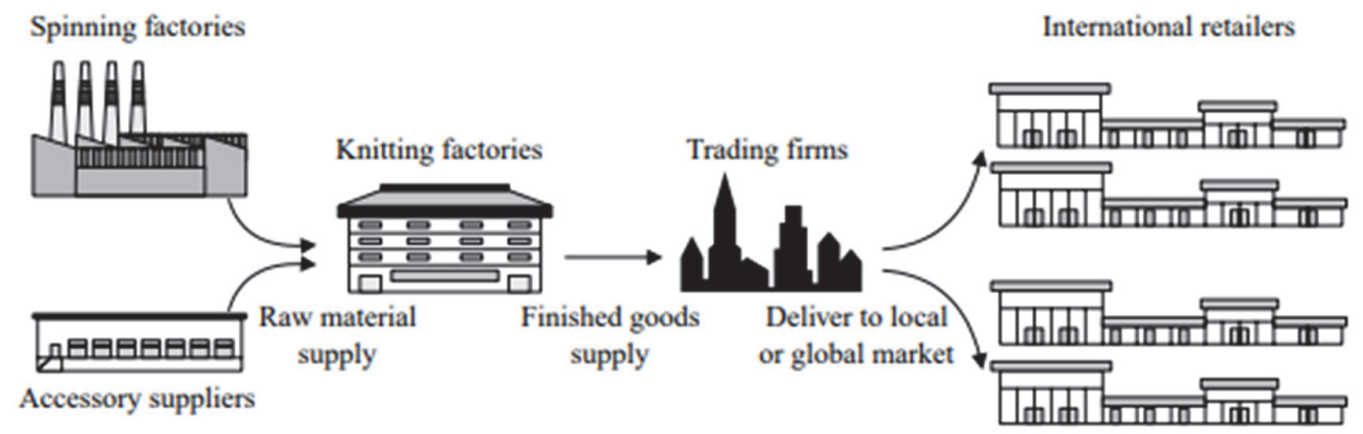

Fig. 1. Supply chain network in the apparel industry

Source: Keung Kwok and Wu (2009)

Various issues present in the textile industry is more probable subject to regular variables and introduce various supply chain interventions to overcome problems. Short item life cycle, long creation lead time, and high anticipating errors are basic issues found in the textile industry (Lam \& Postle, 2006). To control these issues, the RFID technology through information communication technology (ICT) is recommended. Fig. 1 shows how RFID is important to resolve issue and increases the quality of the services by decreasing the delivery time.

As per the Newspaper (2017), a supply chain management includes the arranging and management of everything being equal engaged with sourcing and acquirement, transformation, and all coordination's management exercises. In an intra-supply chain, collaborative supply chain organizes collaborators and connected to upgrade the straightforwardness of real-time information. Fig. 1 and Fig. 2 demonstrate inner supply chain process in which information communication technology (ICT), effective delivery time and staff services quality are important. The textile industry is a case for a coordinated supply chain, as seen by prior studies (Abernathy et al., 1999) and proclaimed that the textile industry is a worldwide framework. In a conventional textile industry, supply chain parties in a worldwide aggressive condition confront inescapable issues, for example, long transportation, long lead time, short item life cycle, and unusual request. Bruce et al. (2004) discussed with four organizations, including a fiber maker, an outsourcing organization, an outlining organization, and a retailer, in the clothing and 
textile industry with the point of distinguishing issues and arrangements, all of which exist in supply chain tasks.

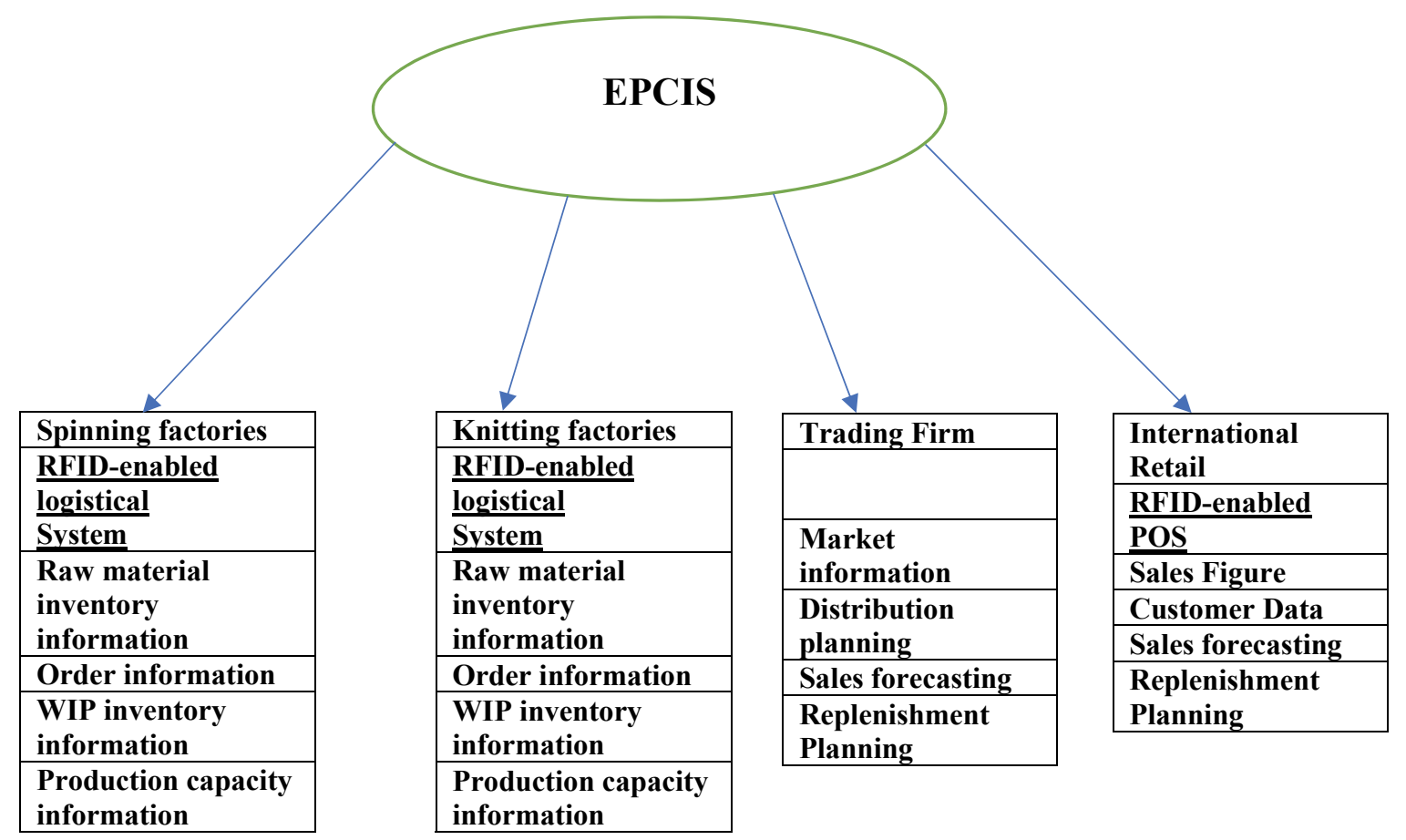

Fig. 2. Radio frequency identification (RFID) technology is a newly emerging technology for the apparel industry based on information Communication Technology (ICT) (Source: Keung Kwok and Wu (2009))

In 2003, the RFID technology started to rise in supply chain operations (Delen et al., 2007). Big suppliers, for example, Procter and Gamble, Gilletter, and Kraft, co-worked with Walmart and effectively actualized RFID technology in a retail supply chain. Angeles (2005) expressed that Kitchen Inc. connected the RFID technology to its appropriation focus and spared $\$ 16.7$ million in labor costs, and $\$ 6.9$ million in errors due to paperwork as well as vendor mistakes. In retailer distribution center management, it is to work on latest technologies in supply chain which can facilitate low transit time and good staff services quality. However, political influence and supply chain investors investment decision making have also contribution in performance (Maqbool et al., 2018).

Srivastava (2004) expressed that applying RFID technology at any level improves the capacity to follow the correct areas of the dead inventory. As demonstrated by previous studies (Chow et al., 2005; Chow et al., 2006), the RFID technology expands the productivity of operations in the distribution center and decreases operational expenses. It additionally enhances accuracy of item traceability. These cases show that RFID technology is useful for the change of item stream and for the improvement of overall revenues at each phase of the supply chain. Therefore, RFID is one of the systems which is based on information communication technology and enhances the delivery system and staff services quality to increase supply chain operation.

The Electronic Product Code Information Services (EPCIS) gives information combination and information-sharing inside the supply chain. The framework design of the RFID-based intra-supply chain is partitioned into four stages: the RFID entryway, information coordination stage, intra-supply chain information reconciliation stage, and electronic stage (Keung Kwok \& Wu, 2009). However, in this process, information communication technology (ICT) plays the key role, which facilitates quality 
services by staff of supply chain and minimum delivery time which ultimately effects positively on Textiles and Apparels Industry performance.

It is evident from the various studies, information communication technology (ICT) contributes towards logistic/supply chain performance (Imran et al., 2019). Latest technologies by facilitates logistic operations through decreasing the overall time. It allows the system to deal through computers which is time saving. However, enterprise risk management is also important to manage operations.

Information communication technology (ICT) improves the products and services of companies and permits new forms of partnership between various consumers as well as suppliers by different websites. It is compulsory for supply chain process to advance not only suitable and safe but also reliable with respect to security in payment transection (Changchit et al., 2009; Chen \& Barnes, 2007; Janaki et al., 2018). Therefore, information and communication technology (ICT) has significant positive role in supply chain activities which ultimately enhances the textiles and apparels industry performance. Therefore, from the above discussion, it is hypothesized that;

Hypothesis 1 (H1): Information communication technology (ICT) has significant positive relationship with textiles and apparels industry supply chain operations.

Moreover, effective delivery time is also an important element of supply chain process which is called transit time. Here the distribution channels has the key role to address effective transit time. This a possible through better RFID system through information and communication technology (ICT). As IT capability of supply chain firm has significant role in operations.

Distribution is significant element of any supply chain system (Gunasekaran \& Ngai, 2003). It comprises delivery of goods to the real customer. The logistics operations comprise of inputting, storing, transporting and allotting physical goods to the end customers (Gunasekaran \& Ngai, 2003). Delivery of goods experiences a reasonable fee, which usually is charged by customers and has the impact on customer satisfaction and ultimately influences significantly on the overall performance. Here, the delivery time has the key importance. The customer paid the goods prices is required to insure the delivery of goods in specified time. Thus, it is hypothesized that;

Hypothesis 2 (H2): Effective delivery time has significant positive relationship with textiles and apparels industry supply chain operations.

Logistics service agent's state of mind, external picture of representatives, correspondence with the client, customized service and other related factors can substantially affect the impression of supply chain services. A supply chain organization's staff service quality for its client, the picture, manner, and correspondence help to shape the general quality (Yuanxiao, 2014). Assurance to appropriate logistics service alludes to the endeavor staff's ability to affirm quality services. Staff services quality enhances the supply chain operations and supply chain operations enhances the textiles and apparels industry supply chain performance.

Thai (2013) demonstrates that service quality is typically comprising of an attribute. Xin and Bo (2004) examined the service quality, its numerous assessment standard feature and found that it has major effect on the profitability of firms. Moreover, according to Hua and Jing (2015), staff service quality has important as well as positive association with e-logistic customer satisfaction through better supply chain operations. Hence, it is hypothesized that;

Hypothesis 3 (H3): Staff service quality has significant positive relationship with textiles and apparels industry supply chain operations. 
Hypothesis 4 (H4): Staff services quality significantly moderates the relationship between information communication technology (ICT) and textiles, and apparels industry supply chain operations.

Hypothesis 5 (H5): Staff services quality significantly moderates the relationship between effective delivery time and textiles, and apparels industry supply chain operations.

Nevertheless,

Hypothesis 6 (H6): Supply chain operations has significant positive relationship with textiles and apparels industry performance.

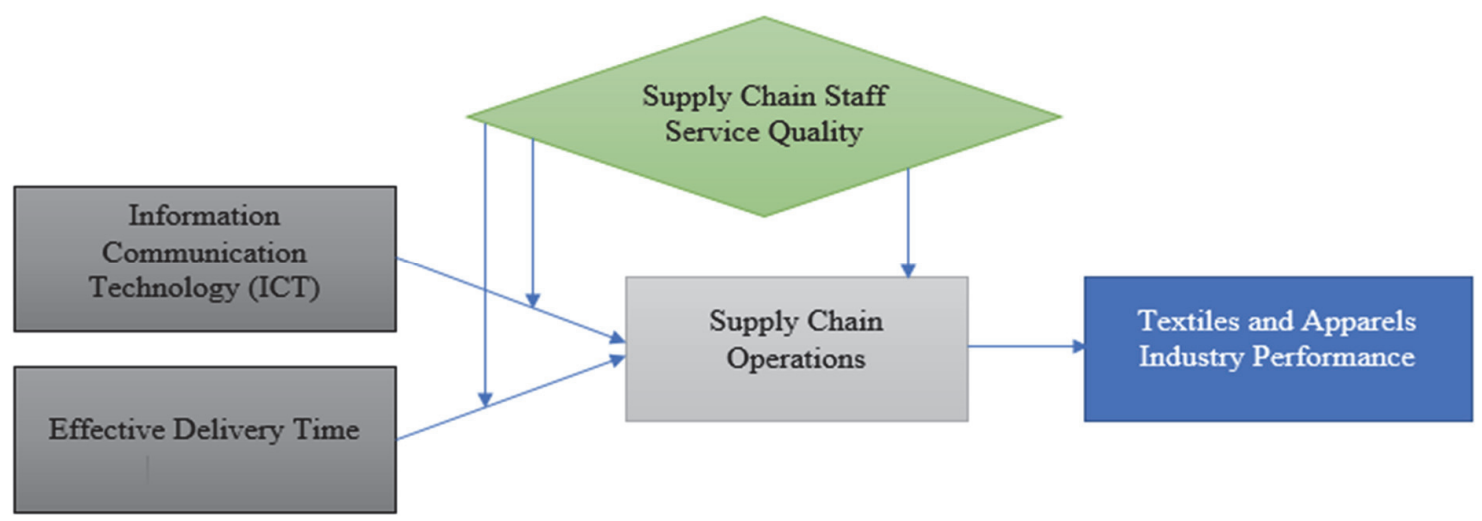

Fig. 3. Theoretical framework of the current study showing effective supply chain practices through Radio frequency identification (RFID) technology

Source: Developed by the current study

\section{Research Methodology}

The population of current study is based on various textiles and apparels companies in Malaysia. Different companies were selected to collect the data. The staff of these companies involved in supply chain activities were selected to collect the data. The staff having no involvement in supply chain activities of textiles and apparels companies were not selected to respond the questionnaires.

Survey was used to collect the data. Data were collected through simple random sampling technique. First of all, the list of all the staff from textiles and apparels companies were obtained and then respondents were chosen, randomly. All the respondents were approached through self-visit to these companies.

As the research method is most crucial, therefore, by examining the nature, problem and objectives of the study, cross-sectional research design was preferred with quantitative research technique. Survey instrument was adapted from previous studies to collect the primary data from textiles and apparels companies.

Moreover, according to Comrey and Lee (1992) inferential statistics states that "sample having less than 50 participants will observed to be a weaker sample; sample of 100 size will be weak; 200 will be adequate; sample of 300 will be considered as good; 500 very good whereas 1000 will be excellent." Therefore, two hundred (200) sample size was selected for this study.

The survey questionnaire was based on two major sections. First sections of the survey questionnaires were comprised of demographic information's of respondents. It includes, age, income, gender, education and marital status. The second major section of the survey questionnaires was consisted of 
items related to major variables, namely; staff services quality, information communication technology (ICT), effective delivery time, supply chain operations and finally items related to textiles and apparels company's performance were stated in the last part of the survey.

\section{Results}

\subsection{Preliminary Analysis}

Before testing the reliability and validity, the preliminary analysis was performed. Preliminary analysis includes; missing value analysis, outlier and normality distribution. While preliminary analysis, it was found that data has no missing value. Moreover, it was also found that data has not outlier.

After that the normality of data was examined by using Skewness and Kurtosis values. From Skewness and Kurtosis values, it was found that few values are not within satisfactory range and distribution is slightly not normal. To overcome this issue, Smart PLS was used to analyze the data. As Smart PLS is one of the software which does not require normal distribution of data.

\subsection{Structural Equation Modelling}

After preliminary analysis, structural equation modelling was utilized to check the reliability and validity. As it is one of the mandatory step before hypotheses testing. In this process, factor loading, Cronbach alpha, composite reliability and average variance extracted (AVE) was examined. According to Hair (2010), items having factor loading below 4.0 should be deleted. Moreover, the value of composite reliability and average variance extracted (AVE) should be more than or equal to 0.7 and 0.5 , respectively. While measurement model assessment, it was found that all the items have factor loading more than 0.7. Fig. 4 shows factor loadings and Table 2 shows the results of the measurement model assessment. Moreover, the discriminant validity was observed by square root of average variance extracted (AVE). Table 3 displays the discriminant validity which is attained by this study.

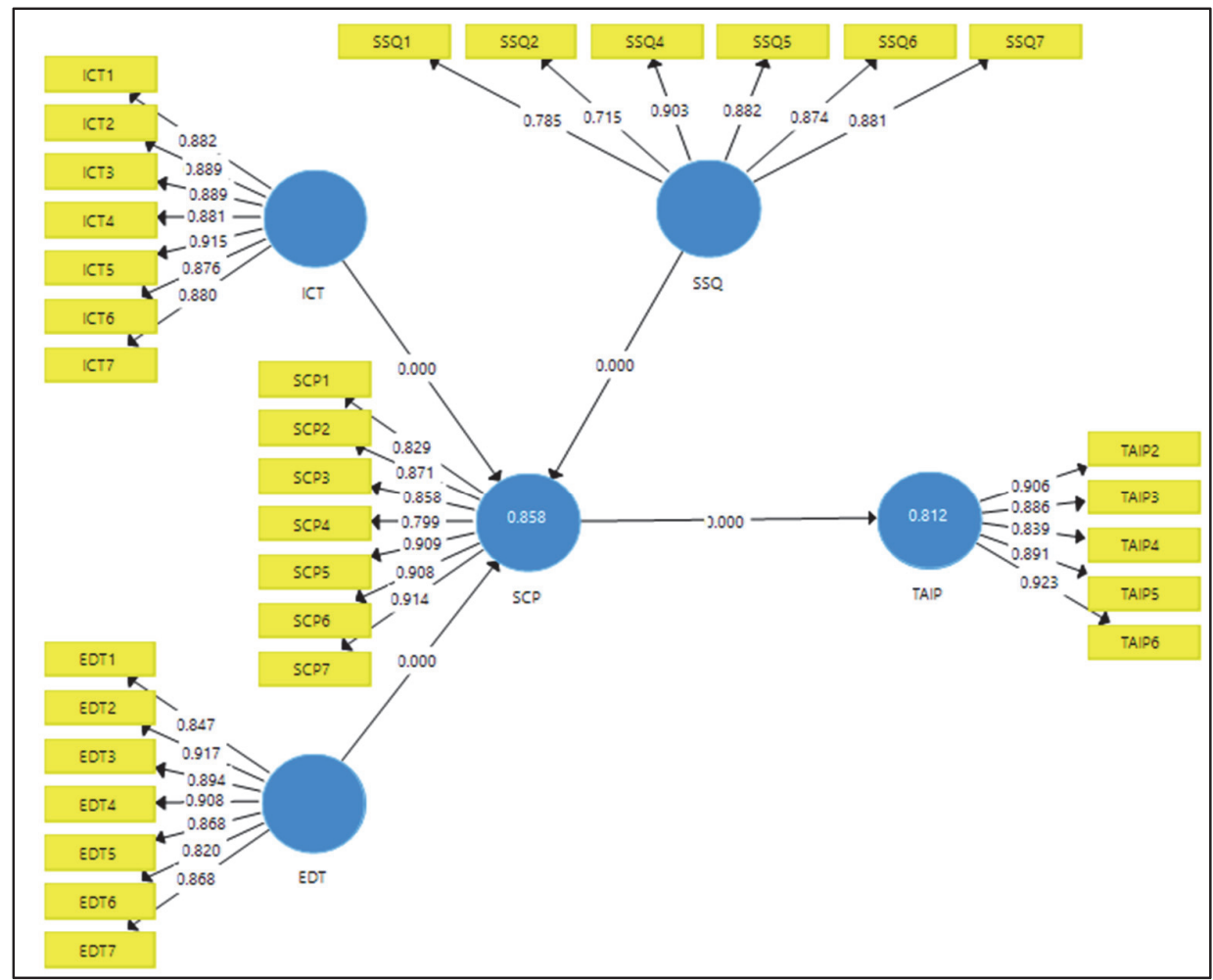

Fig. 4. Measurement Model Assessment 


\section{Table 2}

Results of Measurement Model Assessment

\begin{tabular}{llll}
\hline Indicators & Cronbach Alpha & Composite Reliability & AVE \\
\hline Effective Delivery Time (EDT) & 0.742 & 0.865 & 0.512 \\
Information Communication Technology (ICT) & 0.710 & 0.880 & 0.501 \\
Staff Service Quality (SSQ) & 0.912 & 0.902 & 0.622 \\
Supply Chain Operation (SCO) & 0.781 & 0.816 & 0.592 \\
Textiles and apparels industry performance (TAIP) & 0.799 & 0.781 & 0.509 \\
\hline
\end{tabular}

\section{Table 3}

Discriminant Validity

\begin{tabular}{lllllll}
\hline & 1 & 2 & 3 & 4 & 5 & 6 \\
\hline EDT & 0.748 & & & & & \\
ICT & 0.721 & 0.888 & & & \\
SSQ & 0.478 & 0.720 & 0.701 & & \\
SCO & 0.517 & 0.688 & 0.685 & 0.818 & 0.742 \\
TAIP & 0.611 & 0.694 & 0.550 & 0.724 & \\
\hline
\end{tabular}

After analyzing the measurement model assessment, the structural model was analyzed to check the relationship between dependent, independent and moderating variables. For this process, PLS bootstrapping was performed. This bootstrapping was performed on 5000 subsamples with 135 responses. Bootstrapping is a nonparametric technique that permits testing the statistical significance of different PLS-SEM results.

Fig. 5 and Table 4 show the results of PLS bootstrapping. It is evident from the table that all the direct hypotheses are accepted. As the t-value for all the hypothesis is more than 1.96 and significance value is below 0.05. It accepts the H1, H2, H3 and H6.

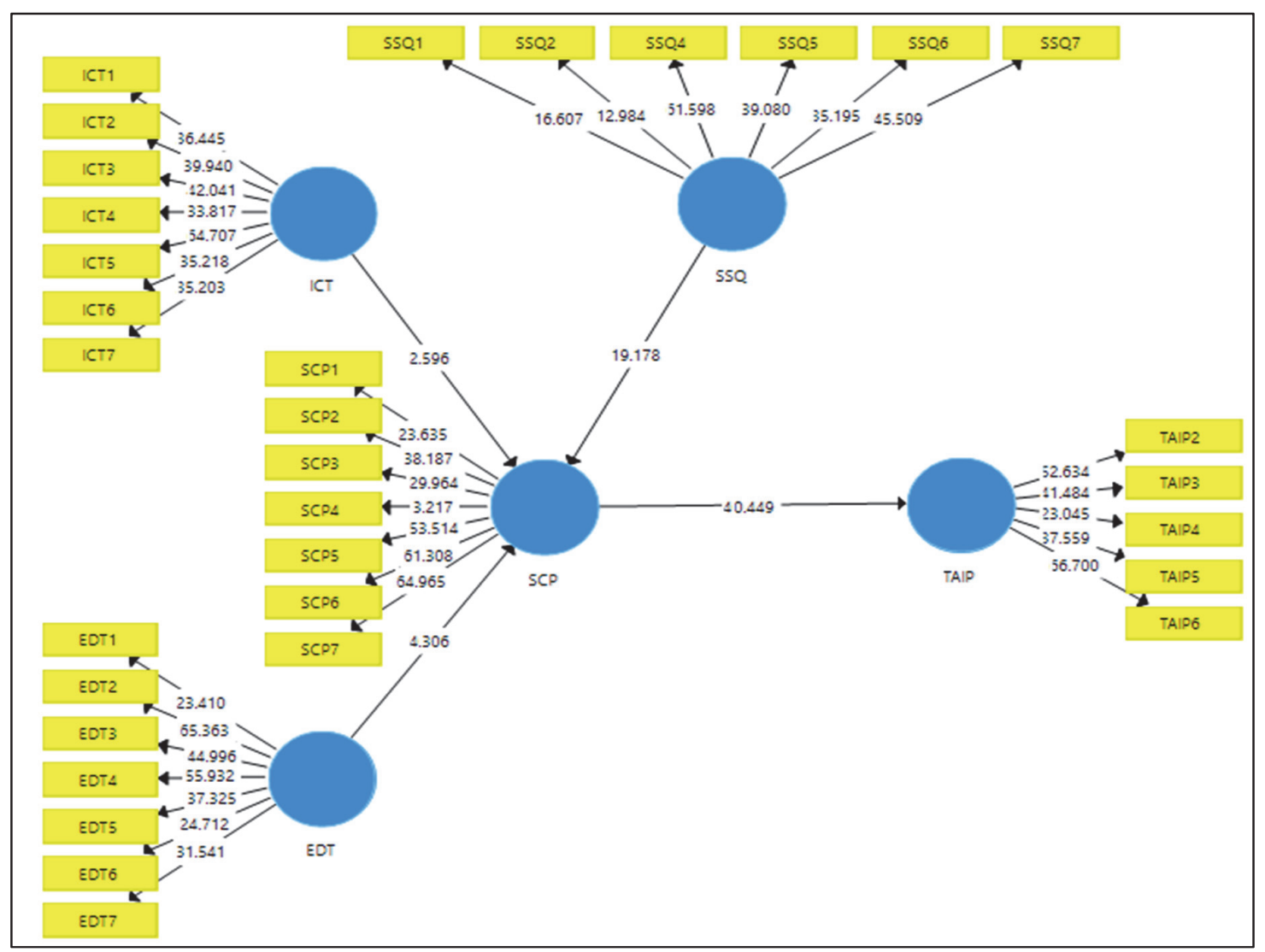

Fig. 5. Structural Model Assessment 
Table 4

Hypotheses Results

\begin{tabular}{lllllll}
\hline Hypotheses & Relationship & $(\beta)$ & SD & T-value & P-Values & Decision \\
\hline H1 & ICT $\rightarrow$ SCO & 0.239 & 0.092 & 2.596 & 0.010 & Supported \\
H2 & EDT $\rightarrow$ SCO & 0.131 & 0.030 & 4.306 & 0.000 & Supported \\
H3 & SSQ $\rightarrow$ SCO & 0.910 & 0.048 & 19.178 & 0.000 & Supported \\
H6 & SCO $\rightarrow$ TAIP & 0.901 & 0.022 & 40.449 & 0.000 & Supported \\
\hline
\end{tabular}

In case of moderation effect, it is evident from Table 5 that the t-value is more than 1.96 in case of effective delivery time, however, t-value is below 1.96 in case of moderation effect between information communication technology and supply chain operations. Thus, staff services quality significantly moderates the relationship of effective delivery time and supply chain operations. Moderation results are shown in Table 5.

Table 5

Moderation Effect Results

\begin{tabular}{lllllll}
\hline Hypotheses & Relationship & $(\beta)$ & SD & T-value & P-Values & Decision \\
\hline H4 & ICT $\times$ SSQ $\rightarrow$ SCO & 0.210 & 0.121 & 1.735 & 0.091 & Not Supported \\
H5 & EDT $\times$ SSQ $\rightarrow$ SCO & 0.303 & 0.101 & 2.990 & 0.020 & Supported \\
\hline
\end{tabular}

Moreover, Table 6 shows the R-square value. According to the results, the R-square value is 0.812 which is strong value (Chin, 1998). It indicates that all the variables collectively explain $81.2 \%$ variance in dependent variable.

Table 6. R-Square $\left(\mathrm{R}^{2}\right)$ Value

\begin{tabular}{lc}
\hline Latent Variable & Variance Explained $\left(\mathrm{R}^{2}\right)$ \\
\hline Textiles and apparels industry performance & 0.812 \\
\hline
\end{tabular}

\section{Findings}

The results of the study have revealed that staff services quality and information communication technology had significant positive relationship with supply chain operations. Skilled staff service quality and information communication technology will enhance supply chain operation in textiles and apparels industry. However, low quality services and information communication technology will affect negatively on operations. Moreover, better supply chain operation leads towards better performance. Furthermore, staff services quality has also direct effect on supply chain operations.

In case of moderating role of staff services quality, the moderation effect is significant in case of effective delivery time. However, moderation effect is insignificant in case of information communication technology. Therefore, it demonstrates that staff services quality moderates the relationship between effective delivery time and supply chain operations.

Fig. 6 shows the direction of moderation effect in case of effective delivery time. According to the findings, it is revealed that moderation effect is positive. Staff services quality positively moderates the relationship of effective delivery time and supply chain operations. Moderation effect enhances the positive effect of effective delivery time on supply chain operations. 


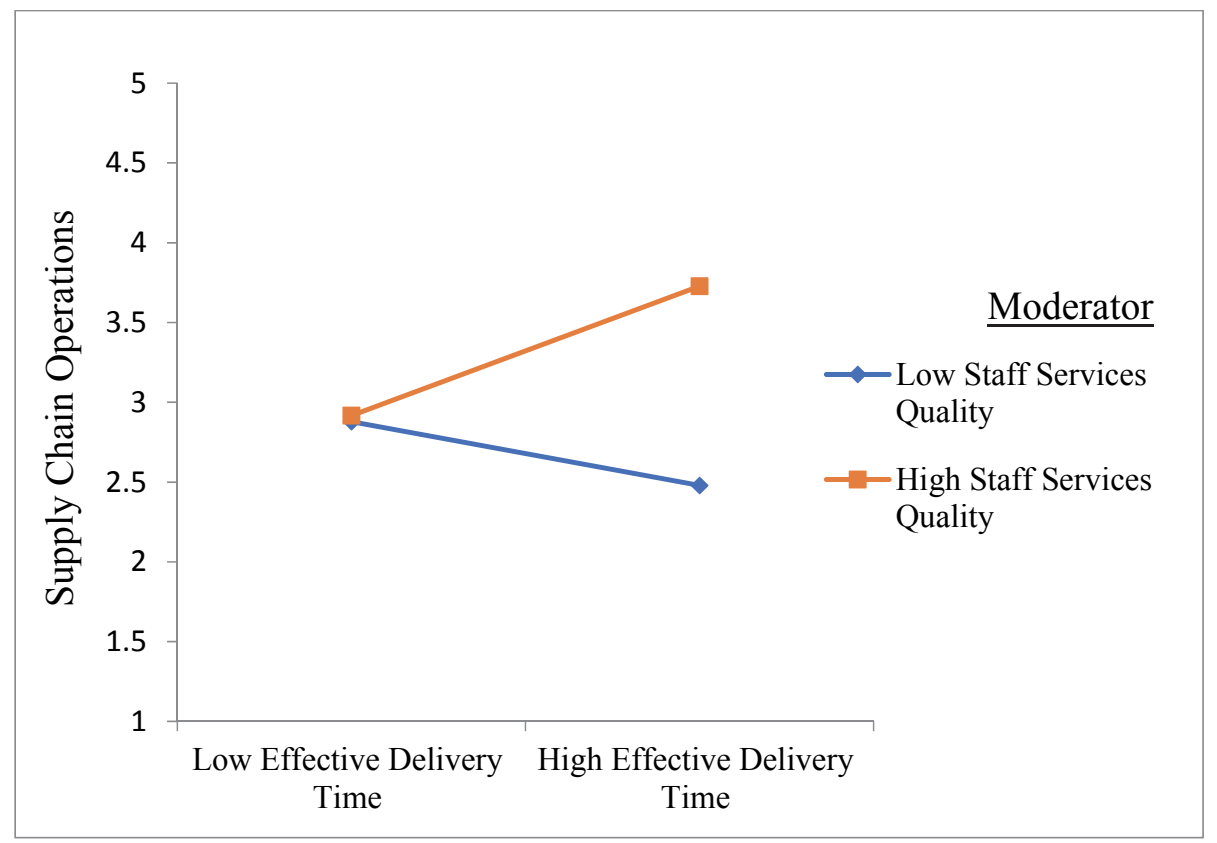

Fig. 6. Staff services quality strengthens the positive effect of effective delivery time on supply chain operations.

Source: Author's own estimations based on analysis results

More importantly, it is found that supply chain operation in textiles and apparels industry has significant influence on overall performance of industry. Increase in supply chain operation increases the performance of industry. Therefore, it is evident that information communication technology and effective delivery time enhances the supply chain operations and supply chain operations enhance the textiles and apparels industry performance.

\section{Conclusion}

The current study has been majorly based on textiles and apparels industry of Malaysia. The effect of radio frequency identification (RFID) technology was examined on supply chain operations by considering the information communication technology and effective delivery time. The employees of textiles and apparels companies were selected as the respondents.

Findings of the study investigated that radio frequency identification (RFID) was one of the most important elements of textiles and apparels industry. It has significant role to boost performance through improvement in supply chain operations. Effective delivery system is generally based on radio frequency identification (RFID) which has positive role to enhance supply chain operations. Moreover, information communication technology is also one of the components of the radio frequency identification (RFID). Better information communication technology has major contribution in payment system, traceability of order, communication with customers and employees which has key role in supply chain operations. In this process, quality of services provided by staff is important. Good quality services decrease the delivery time and enhances communication between company and partners which has vital role to enhance company performance. Future research is needed to apply open innovation strategies in the framework of the current study (Hameed et al., 2018; Salem et al., 2016, 2018).

\section{Acknowledgements}

The authors gratefully acknowledge University College of Technology Sarawak for funding the publication of this research paper. 


\section{References}

Abernathy, F. H., Dunlop, J. T., Hammond, J. H., \& Weil, D. (1999). A stitch in time: Lean retailing and the transformation of manufacturing--lessons from the apparel and textile industries: Oxford University Press.

Angeles, R. (2005). RFID technologies: supply-chain applications and implementation issues. Information Systems Management, 22(1), 51-65.

Azmi, F., Abdullah, A., Bakri, M., Musa, H., \& Jayakrishnan, M. (2018). The adoption of halal food supply chain towards the performance of food manufacturing in Malaysia. Management Science Letters, 8(7), 755-766.

Bruce, M., Daly, L., \& Towers, N. (2004). Lean or agile: a solution for supply chain management in the textiles and clothing industry? International Journal of Operations \& Production Management, 24(2), 151-170.

Changchit, C., Garofolo, T., \& Gonzalez, J. J. (2009). A Cultural Study of E-Commerce Trust: Hispanic Versus Anglo. Journal of Information Science \& Technology, 6(4).

Chen, Y.-H., \& Barnes, S. (2007). Initial trust and online buyer behaviour. Industrial Management \& Data Systems, 107(1), 21-36.

Chin, W. W. (1998). The partial least squares approach to structural equation modeling. Modern Methods for Business Research, 295(2), 295-336.

Chow, H. K., Choy, K., \& Lee, W. (2005). Design of a RFID-based resource management system for warehouse operation. Paper presented at the Industrial Informatics, 2005. INDIN'05. 2005 3rd IEEE International Conference on.

Chow, H. K., Choy, K. L., Lee, W., \& Lau, K. (2006). Design of a RFID case-based resource management system for warehouse operations. Expert systems with applications, 30(4), 561-576.

Comrey, A., \& Lee, H. (1992). A First Course in Factor Analysis (2nd edn.) Lawrence Earlbaum Associates. Publishers: Hillsdale, New Jersey.

Delen, D., Hardgrave, B. C., \& Sharda, R. (2007). RFID for better supply-chain management through enhanced information visibility. Production and Operations Management, 16(5), 613-624.

Douglas, S. U. (1989). The textile industry in Malaysia: coping with protectionism. Asian Survey, 29(4), 416-438.

Gunasekaran, A., \& Ngai, E. W. (2003). The successful management of a small logistics company. International Journal of Physical Distribution \& Logistics Management, 33(9), 825-842.

Hair, J. F. (2010). Black, WC, Babin, BJ, \& Anderson, RE (2010). Multivariate data analysis, 7.

Hameed, W., Basheer, F., Muhammad, Iqbal, J., Anwar, A., \& Ahmad, K., Hafiz. (2018). Determinants of Firm's Open Innovation Performance and the Role of R \& D Department: An Empirical Evidence from Malaysian SME's. Journal of Global Entrepreneurship Research, 8(1).

Hua, W., \& Jing, Z. (2015). An Empirical Study on E-commerce Logistics Service Quality and Customer Satisfaction. WHICEB.

Imran, M., Hamid, S., Aziz, A., \& Hameed, W. (2019). The contributing factors towards e-logistic customer satisfaction: a mediating role of information Technology. Uncertain Supply Chain Management, 7(1), 63-72.

Janaki, D., Izadbakhsh, H., \& Hatefi, S. (2018). The evaluation of supply chain performance in the Oil Products Distribution Company, using information technology indicators and fuzzy TOPSIS technique. Management Science Letters, 8(8), 835-848.

Kelepouris, T., Pramatari, K., \& Doukidis, G. (2007). RFID-enabled traceability in the food supply chain. Industrial Management \& Data Systems, 107(2), 183-200.

Keung Kwok, S., \& Wu, K. K. (2009). RFID-based intra-supply chain in textile industry. Industrial Management \& Data Systems, 109(9), 1166-1178.

Lam, J. K., \& Postle, R. (2006). Textile and apparel supply chain management in Hong Kong. International Journal of Clothing Science and Technology, 18(4), 265-277.

Lim, S.-L., Chu, W.-L., \& Phang, S.-M. (2010). Use of Chlorella vulgaris for bioremediation of textile wastewater. Bioresource Technology, 101(19), 7314-7322. 
Maqbool, N., Hameed, W., \& Habib, M. (2018). Impact of political influences on stock returns. International Journal of Multidisciplinary Scientific Publication (IJMSP), 1(1).

Newspaper, N. S. P. (2017). Special Coverage on Malaysia Textile and Apparel Industry. http://www.mweusg.com/blog/?p=13433.

Pang, Y. L., \& Abdullah, A. Z. (2013). Current status of textile industry wastewater management and research progress in Malaysia: a review. Clean-Soil, Air, Water, 41(8), 751-764.

Salem, M. A., Shawtari, F., Shamsudin, M. F., \& Hussain, H. B. I. (2018). The consequences of integrating stakeholder engagement in sustainable development (environmental perspectives). Sustainable Development, 26(3), 255-268.

Salem, M. A., Shawtari, F. A., Shamsudin, M. F., \& Hussain, H. I. (2016). The relation between stakeholders' integration and environmental competitiveness. Social Responsibility Journal, 12(4), 755-769.

Srivastava, B. (2004). Radio frequency ID technology: The next revolution in SCM. Business Horizons, 47(6), 60-68.

Thai, V. V. (2013). Logistics service quality: conceptual model and empirical evidence. International Journal of Logistics Research and Applications, 16(2), 114-131.

Xin, L., \& Bo, Y. (2004). Service Quality Evaluation of characteristics and service recovery strategies [J]. Management Science, 6(6), 72-76.

Yuanxiao, Z. (2014). A study of evaluation logistic perceived services quality in B2C e-commerce. Master dissertation, Donghua University.

Zare Mehrjerdi, Y. (2008). RFID-enabled systems: a brief review. Assembly Automation, 28(3), 235245.

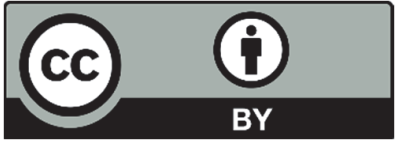

(C) 2019 by the authors; licensee Growing Science, Canada. This is an open access article distributed under the terms and conditions of the Creative Commons Attribution (CC-BY) license (http://creativecommons.org/licenses/by/4.0/). 